\title{
Processed Meat Protein and Heat-Stable Peptide Marker Identification Using Microwave-Assisted Tryptic Digestion
}

\author{
Magdalena Montowska* and Edward Pospiech \\ Institute of Meat Technology, Poznan University of Life Sciences, Wojska Polskiego 31, \\ PL-60-624 Poznan, Poland \\ Received: November 22, 2015 \\ Accepted: May 20, 2016
}

\begin{abstract}
Summary
New approaches to rapid examination of proteins and peptides in complex food matrices are of great interest to the community of food scientists. The aim of the study is to examine the influence of microwave irradiation on the acceleration of enzymatic cleavage and enzymatic digestion of denatured proteins in cooked meat of five species (cattle, horse, pig, chicken and turkey) and processed meat products (coarsely minced, smoked, cooked and semi-dried sausages). Severe protein aggregation occurred not only in heated meat under harsh treatment at $190{ }^{\circ} \mathrm{C}$ but also in processed meat products. All the protein aggregates were thoroughly hydrolyzed after $1 \mathrm{~h}$ of trypsin treatment with short exposure times of 40 and $20 \mathrm{~s}$ to microwave irradiation at 138 and $303 \mathrm{~W}$. There were much more missed cleavage sites observed in all microwave-assisted digestions. Despite the incompleteness of microwave-assisted digestion, six unique peptide markers were detected, which allowed unambiguous identification of processed meat derived from the examined species. Although the microwave-assisted tryptic digestion can serve as a tool for rapid and high-throughput protein identification, great caution and pre-evaluation of individual samples is recommended in protein quantitation.
\end{abstract}

Key words: protein aggregation, thermal denaturation, enzymatic cleavage acceleration, microwave irradiation, mass spectrometry, peptide markers

\section{Introduction}

Mass spectrometry-based proteomics has become an increasingly popular area of research in food science studies on protein interactions, identification and quantification. Although modern, sensitive and high resolution mass spectrometry instruments with bioinformatic tools enable large-scale proteomic studies, sample preparation is a factor impeding rapid and high-throughput screening of processed food. The complexity of food matrices, processes of protein denaturation and aggregation as well as long duration of protein digestion are the main hurdles in the identification of processed proteins and peptides in any traditional workflow. Recently, a number of new tools have been introduced to speed up protein identification (1). The application of microspin columns, ultrasonic, in- frared, microwave energy, high pressure or microreactors substantially reduced the sample preparation time, involving the steps of protein solubilization, reduction, alkylation, and digestion. The drawback of these new methods is that some instruments are expensive when commercially available, for instance powerful ultrasonic baths or microreactors. These new methods have been successfully implemented for protein analysis of simple mixtures and whole proteomes, but they have not been widely tested on processed food.

In traditional protocol, enzymatic digestion of proteins takes from several hours to overnight to produce high amounts of peptides with high coverage of the peptide sequence. Microwave technology is an alternative approach which speeds up the enzymatic cleavage of pro- 
teins for mass spectrometry analysis by reducing the time of digestion from several hours to a few minutes in many biological applications. Microwaves have been applied to digest standard protein solutions, such as cytochrome $\mathrm{c}_{\text {, }}$ myoglobin, lysozyme, ubiquitin (2-4), bovine serum albumin, human urinary proteins, yeast lysate $(5,6)$, and proteins captured on the affinity surfaces of protein chips (7) as well as ultrafast microwave-assisted in-tip digestion of standard proteins and milk extract (8). Enhanced speed and digestion efficiency were observed when specialized, temperature-controlled microwave reactors as well as inexpensive domestic microwave ovens were used $(5,7)$. Thus, simplicity at low cost is a big advantage of microwave irradiation over other tools accelerating proteolysis for high-throughput analysis.

Proteins can lose their solubility due to the lack of a net charge and repulsive interactions between their molecules. An increase in the surface hydrophobicity of proteins leads to protein-protein interactions and their aggregation during thermal treatment, although the primary structure of proteins is often not affected (9-11). The formation of highly insoluble protein aggregates may have negative effect on enzymatic digestion, on sequence coverage of the proteins, and consequently on the efficiency of protein identification. The sequence coverage is the percentage of the protein sequence covered by matched peptides. The larger the sequence coverage is, the more of the protein sequence is confirmed by the experimental analysis. Using standard proteome extraction methods, we observed previously that sequence coverage in selected cooked meat proteins was lower than in raw meat (12), while proper digestion of the analyzed material is essential to develop an efficient method of protein quantification.

In this study we wanted to determine if a rapid microwave-assisted digestion could improve efficient recovery of peptides from industrially processed samples. First we investigated the degree of protein aggregation after heat treatment. Subsequently, the most denatured meat samples and processed meat products digested under the microwave-assisted protocol were analysed using tandem mass spectrometry in order to detect peptide markers that were unique to the examined proteins and species. The application of microwave technology as a tool for fast sample preparation in proteomic studies of processed food is evaluated.

\section{Materials and Methods}

\section{Materials}

Water, acetonitrile, formic acid, and methanol of LC-MS grade were purchased from Sigma-Aldrich (Schnelldorf, Germany). Ammonium hydrogen carbonate, dithiothreitol (DTT), iodoacetamide (IAA) and all other chemicals were of molecular biology grade and obtained from Sigma-Aldrich. Sequence-grade modified trypsin was bought from Promega GmbH (Mannheim, Germany). Meat samples of five species, i.e. cattle, horse, pig, chicken and turkey (longissimus muscle or pectoralis major muscle of poultry) and meat products (four different coarsely minced, smoked, cooked and semi-dried sausages) were purchas- ed locally. Samples of about $5 \mathrm{~g}$ or $5 \mathrm{~cm}$ length were cut from raw or processed products and kept at $-80{ }^{\circ} \mathrm{C}$ until further protein analysis. The microwave oven used in this study was domestic model DMR-904 (Daewoo, Roissy-en-France, France) with the maximum output power of $800 \mathrm{~W}$.

\section{Preparation of samples}

Meat slices of about $25 \mathrm{~mm}$ thick were wrapped in aluminium foil and heated in a Rational Combi convection oven model SCC 61 (Landsberg am Lech, Germany) at three thermal cooking procedures: (i) at $190{ }^{\circ} \mathrm{C}$ for 10 min (variant 1), (ii) at $160{ }^{\circ} \mathrm{C}$ for $30 \mathrm{~min}$ (variant 2), and (iii) at $190{ }^{\circ} \mathrm{C}$ until reaching core temperature of $99{ }^{\circ} \mathrm{C}$, which took 38 min (variant 3 ). Washing, digestion and mass spectrometry analysis were performed according to the procedure described previously (13). Thin sections of raw and cooked meat and meat products (slices of $0.5 \mathrm{~g}$ ) were transferred to glass vials and washed to remove contaminants such as physiological salts, fat and other soluble low-molecular-mass compounds. Samples were rinsed twice for $30 \mathrm{~s}$ in ethanol/water (70:30) followed by a 15-second wash in ethanol and then by a 30-second wash in methanol/water (90:10). Then the samples were rinsed twice for $30 \mathrm{~s}$ in deionized water. The washed samples were homogenized in $100 \mathrm{mM}$ of aqueous ammonium hydrogen carbonate in an Ultra-Turrax T25 (IKA Labortechnik, Staufen, Germany) homogenizer twice for $20 \mathrm{~s}$ at $9500 \mathrm{rpm}$ followed by $30 \mathrm{~s}$ at $13500 \mathrm{rpm}$, and speed vacuumed to dry in CentriVap micro IR (Labconco Corporation, Kansas City, MO, USA).

\section{SDS-PAGE analysis}

Sodium dodecyl sulfate-polyacrylamide gel electrophoresis (SDS-PAGE) was performed to establish the extent of protein aggregation as well as to assess the use of microwave technology in acceleration of protein digestion. Dried meat sample of $10 \mathrm{mg}$ was solubilized with lysis buffer (8 M urea, $2 \mathrm{M}$ thiourea, $0.05 \mathrm{mM}$ Tris, $75 \mathrm{mM}$ DTT, $3 \%$ SDS, $0.05 \%$ Bromophenol Blue, at $\mathrm{pH}=6.8$ ). Samples were heated at $98{ }^{\circ} \mathrm{C}$ for $4 \mathrm{~min}$. Protein concentration was determined using a 2-D Quant Kit (GE Healthcare Bio-Sciences, Fairfield, CT, USA). Meat sample extracts (12 $\mu \mathrm{g}$ of protein) or meat digests $(15 \mu \mathrm{L})$ were loaded onto $15 \%$ polyacrylamide gels prepared in Hoefer SE250 systems (GE Healthcare Bio-Sciences). Gels were run at constant current of $20 \mathrm{~mA}$ per gel, until the dye front reached the end of the gel. The gels were stained with Coomassie Brilliant Blue and scanned on an ImageMaster Scanner (GE Healthcare Bio-Sciences).

\section{Image and statistical analysis}

The gel images were analyzed using ImageMaster Platinum software v. 7.0 (GE Healthcare Bio-Sciences). The gels of raw meat samples were compared with the other experimental samples used as control. In order to compare the aggregation of proteins across samples, the intensities of the raw meat samples were summed up and set at $100 \%$. The band intensity values were imported into STATISTICA v. 10 (StatSoft Inc., Tulsa, OK, USA) soft- 
ware. The data were examined by one-way analysis of variance (ANOVA). Least significant differences were set at a $5 \%$ level and evaluated by Scheffe's multiple range tests.

\section{Microwave-assisted tryptic digestion}

Dried samples $(2 \mathrm{mg}$ ) were rehydrated in $100 \mu \mathrm{L}$ of $100 \mathrm{mM}$ ammonium hydrogen carbonate, then $200 \mathrm{mM}$ DTT were added as a reducing agent and incubated for 1 $\mathrm{h}$ at $56^{\circ} \mathrm{C}$. After that, samples were alkylated by the addition of $200 \mathrm{mM}$ iodoacetamide and incubated in the dark for $30 \mathrm{~min}$ at room temperature. The remaining iodoacetamide was quenched by the addition of $200 \mathrm{mM}$ DTT and incubated at room temperature for $30 \mathrm{~min}$. The samples were digested in a solution containing $0.083 \mu \mathrm{g} / \mu \mathrm{L}$ of trypsin in ammonium hydrogen carbonate for $1 \mathrm{~h}$ at 37 ${ }^{\circ} \mathrm{C}$. After initial $30 \mathrm{~min}$, samples were subjected to microwave irradiation for $40 \mathrm{~s}$ at $138 \mathrm{~W}$ in water bath, then placed in a heating block at $37^{\circ} \mathrm{C}$ for $30 \mathrm{~min}$ and microwaved the second time for $20 \mathrm{~s}$ at $303 \mathrm{~W}$. The standard digestion protocol was conducted at $37^{\circ} \mathrm{C}$ over a period of $20 \mathrm{~h}$. The sample digests were purified by reversed-phase extraction using Sep-Pak C18 Plus cartridges (Waters, Milford, MA, USA). Eluted samples were vacuum dried. Prior to mass spectrometry analysis, samples were rehydrated in a solution consisting of $2 \%$ acetonitrile and 0.1 $\%$ formic acid (by volume).

\section{Sequence coverage and peptide identification by mass spectrometry}

Samples were analyzed in chip-based infusion mode via a silicon-based nanoelectrospray ionization (ESI) microchip (nanoESI chip). The ion source was a TriVersa NanoMate (Advion, Ithaca, NY, USA) coupled to a Thermo Scientific Q Exactive Hybrid Quadrupole-Orbitrap mass spectrometer (Thermo Fisher Scientific, San Jose, CA, USA) operated in positive ion electrospray ionization mode. The NanoMate platform operated at nanoESI tip voltage of $1.6 \mathrm{kV}$, with a gas pressure of $2757.9 \mathrm{~Pa}$ and a capillary temperature of $190^{\circ} \mathrm{C}$. All results of data-dependent MS/MS analysis (dd-MS ${ }^{2}$ ) were collected in full scan mode with $\mathrm{m} / \mathrm{z}$ range of 50-2000, at 1 microscan, maximum injection time of $100 \mathrm{~ms}$, and automatic gain control target of 1e6. Collision-induced dissociation (CID) experiments were performed at a normalized collision energy of $28 \%$. Data were analysed using Xcalibur v. 2.1 (Thermo Fisher Scientific) software. For protein and peptide identification, raw files were converted to MASCOT generic format using msconvert ProteoWizard toolkit application (14). The resulting files were searched via MS/MS ion search using MASCOT (15) against the UniProtKB/SwissProt (16) database with the following parameters: trypsin enzyme, taxonomy bone vertebrates, one missed cleavage, peptide mass tolerance of 1.2 Da, MS/MS tolerance of $0.6 \mathrm{Da}$, carbamidomethylation as fixed modification, oxidation of methionine as variable modification, and peptide charges of $2+, 3+$ and $4+$. A decoy search was performed automatically and the matches and MASCOT scores were evaluated at $1 \%$ of the false discovery rate for identity and homology threshold. Selected peptides in FASTA format were searched against the NCBInr database (17) using the protein BLAST alignment research tool and blastp algorithm for species and protein specificity.

\section{Results and Discussion}

\section{Aggregation of meat proteins}

The influence of high temperature on the formation of protein aggregates was investigated by heating meat samples using three cooking procedures as described in Materials and Method section. As the temperature and exposition time increased, gradual aggregation of meat proteins was observed (Fig. 1). The extent of protein aggregation in relation to raw meat is shown in Fig. 2. There was approx. a double increase in protein aggregates in
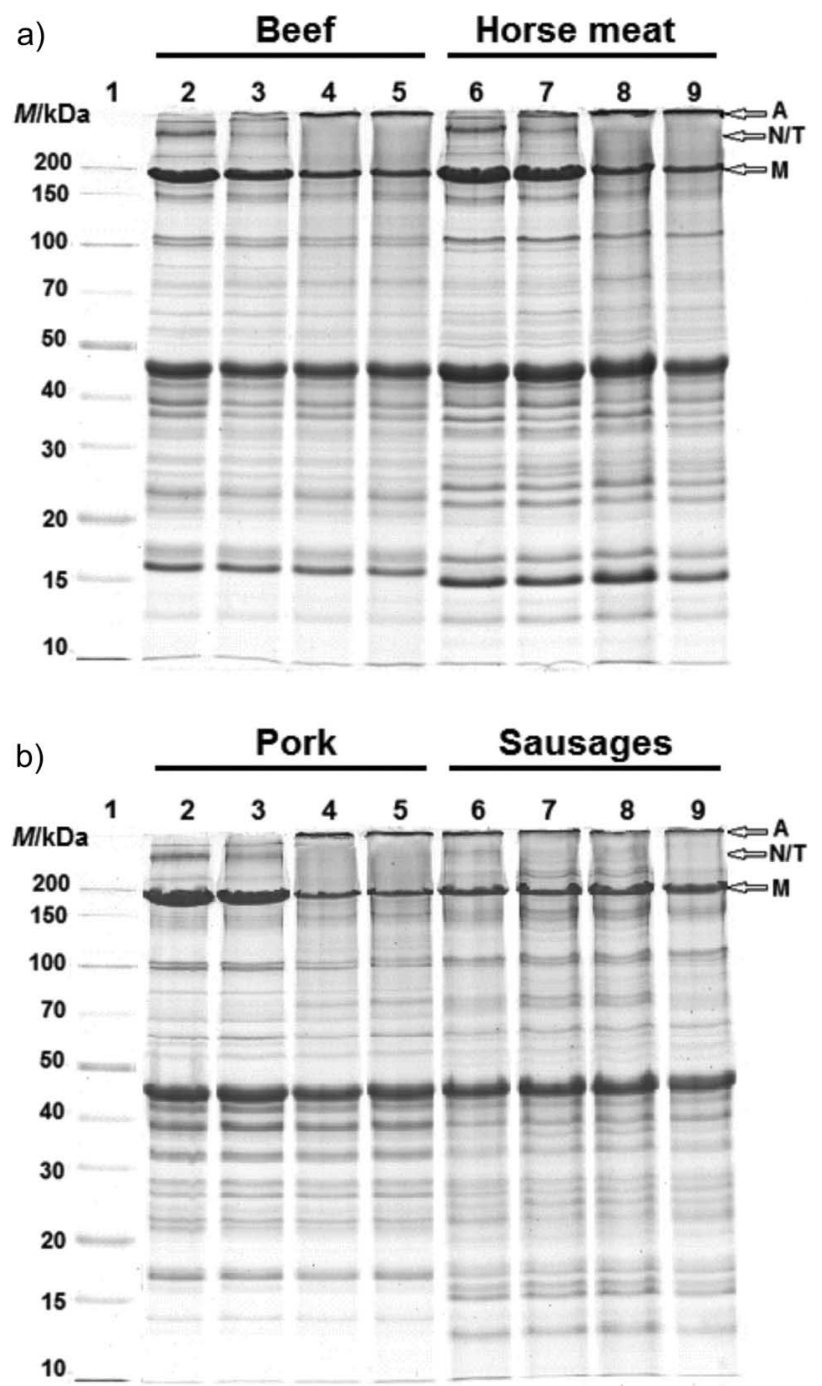

Fig. 1. Representative SDS-PAGE under different thermal conditions: a) lane $1=$ Thermo Scientific unstained protein $M$ ladder, lane $2=$ raw beef, lane $3=$ beef variant 1 , lane $4=$ beef variant 2 , lane 5 =beef variant 3 , lane $6=$ raw horse meat, lane $7=$ horse meat variant 1 , lane $8=$ horse meat variant 2 , lane $9=$ horse meat variant 3 , and b) lane $1=M$ ladder, lane $2=$ raw pork, lane $3=$ pork variant 1 , lane $4=$ pork variant 2 , lane $5=$ pork variant 3 , and lanes 6-9=four different smoked, cooked and semi-dried sausages. The cooking conditions were as follows: at $190{ }^{\circ} \mathrm{C}$ for $10 \mathrm{~min}$ (variant 1), at $160{ }^{\circ} \mathrm{C}$ for $30 \mathrm{~min}$ (variant 2), and at $190{ }^{\circ} \mathrm{C}$ until reaching core temperature of $99^{\circ} \mathrm{C}$ (variant 3). Protein bands show substantial protein aggregation (A), degradation of nebulin/titin degradation products $(\mathrm{N} / \mathrm{T})$ and degradation of myosin heavy chains $(\mathrm{M})$ 


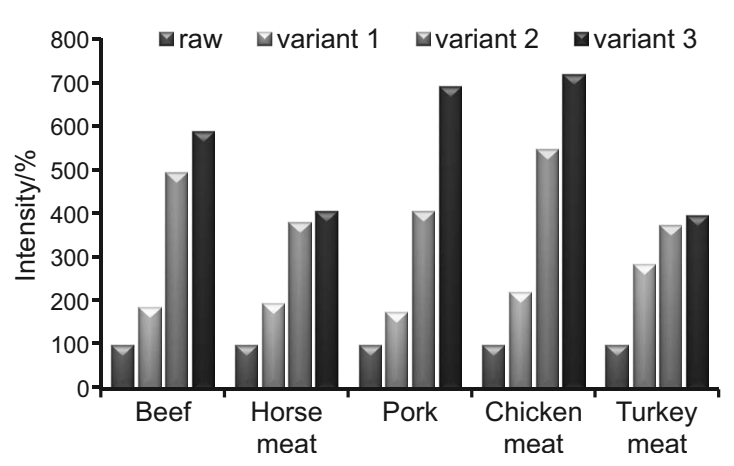

Fig. 2. Protein aggregation in relation to raw meat under three cooking procedures: variant $1=190^{\circ} \mathrm{C}$ for $10 \mathrm{~min}$, variant $2=160{ }^{\circ} \mathrm{C}$ for $30 \mathrm{~min}$, and variant $3=190{ }^{\circ} \mathrm{C}$ until reaching core temperature of $99^{\circ} \mathrm{C}$

variant 1 . Under harsher treatment they became more condensed, up to five- and sevenfold in variants 2 and 3, respectively. Porcine and chicken myofibrillar proteins turned out to be the most susceptible to high temperature. Substantial aggregation was also observed in four different kinds of sausages (Fig. 1b, lanes 6-9).

The high-molecular-mass proteins were gradually degraded as the exposure to heat increased. Fig. 1 shows that the amount of myosin heavy chains cooked under the harsh conditions of variant 3 considerably decreased, as compared with raw meat. On the top of the gel, above the band of myosin heavy chain, the very large nebulin and titin proteins, or their degradation products, were severely altered even in variant 1 and they completely disappeared in variants 2 and 3 . There were less visible changes in proteins of lower molecular mass. For instance, actin, one of the most thermostable proteins (9), turned out to be more resistant even under variant 3 conditions. Lesser degradation of low-molecular-mass proteins was reported in earlier studies $(18,19)$. According to Hofmann (9), meat proteins are not truly degraded during heating but they lose dye-binding basic groups, which means that the protein is still present in the gel, although its ability to be stained is reduced. However, in our previous studies we observed lower MASCOT scores and sequence coverages in processed meat than in raw meat $(12,13)$. This indicates that meat proteins undergo irreversible degradation during thermal treatment and industrial processing, which may affect mass spectrometry-based studies.

\section{Microwave-assisted tryptic digestion of processed meat}

Microwave-assisted protein digestion was investigated in cooked meat using variant 3 procedure and in smoked, cooked and semi-dried sausages. A solution (approx. $0.5 \mathrm{~mL}$ ) of meat, aqueous ammonium hydrogen carbonate and trypsin was subjected to microwave irradiation twice at an interval of $30 \mathrm{~min}$. Fig. 3 presents protein profiles of tryptic digestion of cooked beef after a conventional and microwave-assisted digestion. This preliminary analysis revealed that the microwave treatment time of $1 \mathrm{~h}$ was sufficient to achieve the protein digestion rate similar to the results generated by conventional procedure of $20 \mathrm{~h}$. a)

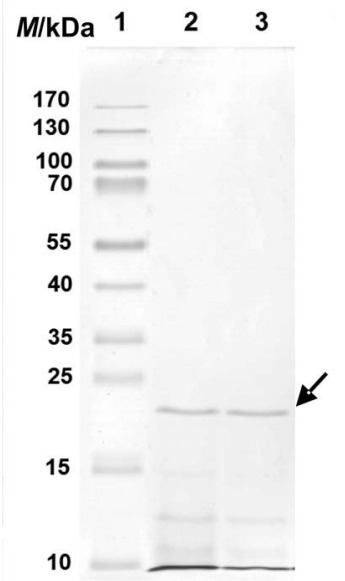

b)

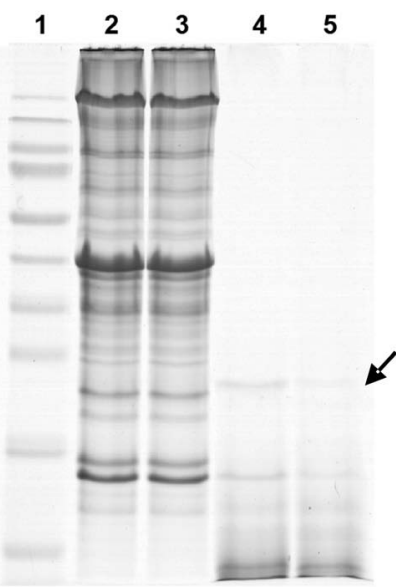

Fig. 3. SDS-PAGE analysis of cooked beef (variant 3) before and after tryptic digestion using the conventional and microwave-assisted procedures: a) lane $1=$ Thermo Scientific prestained protein $M$ ladder, lane $2=$ conventional digestion without protein reduction and alkylation, lane $3=$ conventional digestion with protein reduction and alkylation, and $\mathrm{b})$ lane $1=M$ ladder $(M / \mathrm{kDa})$, lanes 2 and $3=$ undigested beef extracts, lane $4=$ microwave-assisted digestion at $138 \mathrm{~W}$ for $40 \mathrm{~s}$, and lane $5=$ microwave-assisted digestion at $303 \mathrm{~W}$ for $20 \mathrm{~s}$. Arrows indicate trypsin band

The high cost of specialized microwave reactors with internal temperature control prompted us to use a household microwave oven. The reaction temperature was monitored indirectly by measuring the temperature in a water bath. As reported previously (6), enzymatic digestion mixtures absorb microwaves strongly and heat up rapidly, reaching $100{ }^{\circ} \mathrm{C}$ within less than $90 \mathrm{~s}$ at a constant microwave power of $10 \mathrm{~W}$. Since trypsin has the highest activity within a temperature range of $37-50{ }^{\circ} \mathrm{C}$, our sample was heated in two rounds to avoid overheating and enzyme inactivation. In our experiment the reaction temperature reached 44 and $85{ }^{\circ} \mathrm{C}$ at a microwave power of 138 and $303 \mathrm{~W}$, respectively. As was observed by Damm et al. (6), a significant decrease in trypsin activity at high temperature of over $60{ }^{\circ} \mathrm{C}$ probably caused decrease in the trypsin band intensity in our samples (Fig. 3b, lane 5), and consequently the drop of its activity. This observation suggests that irradiation lasting longer than $40 \mathrm{~s}$ at $303 \mathrm{~W}$ would have destroyed the enzyme activity. We evaluated that cooked meat could be digested with the assistance of microwave irradiation within a period of time shortened to approx. $1 \mathrm{~h}$. Our next objective was to assess the protein digestion efficiency and the ability to detect unique peptide markers using the proteomic approach.

\section{Sequence coverage and detection of peptide markers}

Tryptic digestion of cooked meat and sausage samples was analysed by data-dependent MS/MS using MASCOT searching. Table 1 shows the number of identified peptides and sequence coverages of the most abundant proteins of cooked beef obtained with and without microwave irradiation. Horse proteins identified after conventional and microwave-assisted tryptic digestion of sausages made from pork and horse meat are presented in Table 2. The percentage of incomplete digestion, defined 
Table 1. Dominant proteins identified after conventional and microwave-assisted tryptic digestion of cooked beef

\begin{tabular}{|c|c|c|c|c|c|c|}
\hline \multirow{2}{*}{$\begin{array}{l}\text { Identified } \\
\text { protein }\end{array}$} & \multicolumn{3}{|c|}{ Conventional digestion } & \multicolumn{3}{|c|}{ Microwave-assisted digestion } \\
\hline & $\begin{array}{l}\text { Matched } \\
\text { peptides* }\end{array}$ & $\begin{array}{c}\text { Sequence } \\
\text { coverage/\%** }\end{array}$ & $\begin{array}{l}\text { MASCOT } \\
\text { score }^{* * *}\end{array}$ & $\begin{array}{l}\text { Matched } \\
\text { peptides* }\end{array}$ & $\begin{array}{c}\text { Sequence } \\
\text { coverage/\%** }\end{array}$ & $\begin{array}{l}\text { MASCOT } \\
\text { score }^{* * *}\end{array}$ \\
\hline Myosin-1 & $64(11.4)$ & 38.1 & 6337 & $39(45.2)$ & 24.1 & 4282 \\
\hline Myosin-2 & $59(18.4)$ & 35.3 & 6227 & $41(46.8)$ & 26.1 & 4385 \\
\hline Myosin-7 & $54(15.1)$ & 33.7 & 5709 & $42(30.3)$ & 25.5 & 5096 \\
\hline Actin & $16(1.2)$ & 62.6 & 6633 & $19(13.8)$ & 65.0 & 7982 \\
\hline Myoglobin & $7(0)$ & 61.7 & 2704 & $10(33.3)$ & 67.8 & 3711 \\
\hline
\end{tabular}

Percentage of missed cleavages is shown in parentheses, ${ }^{*}$ number of matched peptides in the database search, ${ }^{* *}$ percentage of coverage of the entire amino acid sequence, ${ }^{* * *}$ MASCOT score at false discovery rate of $1 \%$

Table 2. Dominant horse proteins identified after conventional and microwave-assisted tryptic digestion of sausages made from pork and horse meat

\begin{tabular}{|c|c|c|c|c|c|c|}
\hline \multirow{2}{*}{$\begin{array}{l}\text { Identified } \\
\text { protein }\end{array}$} & \multicolumn{3}{|c|}{ Conventional digestion } & \multicolumn{3}{|c|}{ Microwave-assisted digestion } \\
\hline & $\begin{array}{l}\text { Matched } \\
\text { peptides* }\end{array}$ & $\begin{array}{c}\text { Sequence } \\
\text { coverage/\% }\end{array}$ & $\begin{array}{l}\text { MASCOT } \\
\text { score }^{* * *}\end{array}$ & $\begin{array}{l}\text { Matched } \\
\text { peptides* }\end{array}$ & $\begin{array}{c}\text { Sequence } \\
\text { coverage/\% }\end{array}$ & $\begin{array}{l}\text { MASCOT } \\
\text { score }^{* * *}\end{array}$ \\
\hline Myosin-1 & $69(14.9)$ & 40.6 & 3550 & $43(32.7)$ & 28.0 & 6063 \\
\hline Myosin-2 & $72(14.5)$ & 42.9 & 3691 & $51(37.9)$ & 34.1 & 6874 \\
\hline Myosin-7 & $49(14.2)$ & 30.3 & 1748 & $38(19.3)$ & 24.6 & 4346 \\
\hline Actin & $13(0.9)$ & 60.5 & 2092 & $17(17.1)$ & 61.8 & 5866 \\
\hline Myoglobin & $5(0)$ & 51.3 & 138 & $5(31.4)$ & 37.7 & 482 \\
\hline
\end{tabular}

Percentage of missed cleavages is shown in parentheses, ${ }^{*}$ number of matched peptides in the database search, ${ }^{* *}$ percentage of coverage of the entire amino acid sequence, ${ }^{* * *}$ MASCOT score at false discovery rate of $1 \%$

as the ratio between the number of peptides with missed cleavages and the total number of detected peptides, is shown in parentheses. Microwave irradiation generated a similar or higher number of matched peptides and sequence coverages of beef myoglobin, where 61.7 and $67.8 \%$ of coverages were observed (conventional vs. microwaveassisted). The myoglobin coverage was lower in the horse and pork sausage samples, indicating higher susceptibility of this protein to industrial processes resulting in reduced digestion efficiency. High-molecular-mass proteins, for instance myosin heavy chain isoforms, were correctly classified according to the species but there were fewer matched peptides and lower sequence coverages of all of the microwaved products under analysis.

Although proteins were digested to peptides, considerably more missed cleavage sites in all microwave-assisted digests of all examined proteins were observed. The analysis of myosin-1 revealed that the percentage of missed cleavages increased from 11.4 to $45.2 \%$ and from 14.9 to $32.7 \%$ in irradiated beef and sausage samples, respectively. This is consistent with the previous study by Reddy et al. (4), where the number of missed cleavage peptides of standard proteins, for instance myoglobin, was found to be higher (34.1 vs. $8.1 \%$ ) in irradiated digestions.

We also examined the applicability of microwave-assisted protein digestion for detection of unique peptide markers for species determination. Data sets were collected with data-dependent MS/MS ion fragmentation for screening of the whole product digestion using a list of heat-stable peptide markers used in our previous studies both for the species selection and protein identification $(12,13)$. The results were evaluated at $1 \%$ of the false discovery rate for peptide identity and homology threshold. Predominantly, detected peptides were ranked first in the list of matched peptides using MASCOT algorithm. The peptide markers observed for the cattle and horse meat are shown in Table 3. Interestingly, despite the incompleteness of microwave-assisted digestion, we were able to detect six most abundant unique peptides, which allowed unambiguous identification of processed meat derived from the examined species. The peptide sequence SALAHAVQSSR unique to two pork myosin isoforms, i.e. myosin- 1 and myosin- 4 was identified with the MASCOT scores below the identity and homology threshold. Most of the $y$ and $b$ ions were observed within the peptide spectra but their intensities were very low. This may indicate that the product was manufactured from the meat of lower class containing high amount of connective tissue and fat or the amount of added pork was low.

The results obtained in this study contradict a great number of previous studies, which found microwave-assisted tryptic digestion faster and more efficient than the conventional protocol. The accelerated rate of digestion as well as a greater sequence coverage have been demonstrated in mass spectrometry analyses of single proteins or biological samples $(1,8,20)$. High sequence coverages of standard proteins, i.e. myoglobin ( $89 \%)$, bovine serum albumin (78 \%) and $\alpha$-casein (83\%) were obtained using ultrafast microwave-assisted in-tip digestion (8). However, when these new enzyme tips were applied to digest 
Table 3. Heat-stable peptide markers unique to the species and protein observed after microwave-assisted tryptic digestion

\begin{tabular}{|c|c|c|c|c|c|c|c|}
\hline \multicolumn{2}{|c|}{$m / z$} & \multirow{2}{*}{ Protein } & \multirow{2}{*}{ Species } & \multirow{2}{*}{$\begin{array}{l}\text { NCBI accession } \\
\text { number }\end{array}$} & \multirow{2}{*}{ Peptide sequence } & \multirow{2}{*}{$\begin{array}{l}\text { MASCOT } \\
\text { ion score }^{*}\end{array}$} & \multirow{2}{*}{$\begin{array}{l}\text { Identity } \\
\text { threshold }\end{array}$} \\
\hline Experimental & Calculated & & & & & & \\
\hline 1531.6691 & 1531.6725 & myoglobin & cattle & gi $\mid 27806939$ & HPSDFGADAQAAMSK & 121 & $>14$ \\
\hline 1998.9654 & 1999.9713 & MLC2f & cattle & gi|115497166 & EASGPINFTVFLNMFGEK & 24 & $>22$ \\
\hline 1605.6654 & 1605.8475 & myoglobin & horse & gi 17546624 & VEADIAGHGQEVLIR & 31 & $>15$ \\
\hline 1377.8338 & 1377.8344 & myoglobin & horse & gil 7546624 & HGTVVLTALGGILK & 73 & $>15$ \\
\hline 1634.7926 & 1634.8008 & myosin-2(2A) & horse & gi|126352470 & VVETMQTMLDAEIR & 25 & $>38$ \\
\hline 2199.1183 & 2200.1011 & myosin-7 & horse & gi|75054114 & GTLEDQIIEANPALEAFGNAK & 41 & $>15$ \\
\hline 1125.5854 & 1125.5891 & $\begin{array}{l}\text { myosin-4(2B) } \\
\text { myosin-1(2X }\end{array}$ & pig & gi|178056718 & SALAHAVQSSR & 3 & $>13$ \\
\hline
\end{tabular}

${ }^{*}$ MASCOT score at false discovery rate of $1 \%,{ }^{* *}$ individual ion scores to indicate identity or extensive homology

proteins extracted from bovine milk, $\alpha$-casein was identified with a lower sequence coverage of $68 \%$. Thus, these results indicate that microwave-assisted digestion may be less effective in the case of very complex biological samples and such are the whole meat product digests. Recently, a comparative analysis between microwave-assisted and conventional tryptic digestion of standard proteins (bovine serum albumin, cytochrome $c$ and $\beta$-casein) performed at the same temperature revealed no significant differences between these protocols in relation to the rate of peptide generation (6). This may indicate that the acceleration of enzymatic cleavage which was observed previously should be attributed to a rapid rise in the reaction temperature rather than direct impact of microwave irradiation/strength of electric field. The positive effect of thermal denaturation prior to tryptic digestion on peptide mass mapping has been reported previously (21). In our study severely denatured meat products were analyzed instead of biologically active proteins. Therefore, the results were only slightly altered by microwave heating and no substantial improvement in peptide recovery was observed.

In our opinion, this rapid microwave-assisted tryptic digestion has a potential to be implemented as a tool for rapid identification of proteins in high-throughput screening of protein mixtures. However, incomplete digestion and the variability of peptide recovery may distort quantitative information, making the protein quantification unreliable, especially with relative, label-free approaches. In such cases, proteins and peptide reference standards or isotope labelling would be recommended in quantitative experiments and the results must be cautiously verified for each individual approach.

\section{Conclusions}

This study examined the applicability of the microwave-assisted tryptic digestion for rapid and efficient recovery of peptide markers from industrially processed meat products. We demonstrated that substantial protein aggregates formed during microwave irradiation and heating could be enzymatically hydrolyzed within the digestion time shortened to approx. $1 \mathrm{~h}$. Proteins and heat-stable peptide markers were correctly identified by mass spectrometry analysis. However, lower sequence cover- age of high-molecular-mass proteins as well as greater number of missed cleavage peptides indicate the incompleteness of microwave-assisted protein digestion. Nevertheless, six peptide markers unique to cattle, horse and pig were detected, which allowed unambiguous identification of processed meat derived from the examined species. The results obtained in the study show that microwave heating has a potential to be implemented in rapid high-throughput screening of processed proteins only for qualitative purposes. We expect that the microwave-assisted protein digestion combined with quantitative proteomic experiments would be more reliable with the labelling of proteins or peptides than label-free approaches, but this hypothesis needs to be verified in the future.

\section{Acknowledgements}

The study was supported by the National Science Center in Poland based on Decision No. DEC-2013/11/D/ NZ9/02632. We are grateful to Prof. Dr. Piotr Kachlicki, Institute of Plant Genetics, Polish Academy of Sciences, for continuous collaboration and providing access to QExactive and TriVersa NanoMate instruments.

\section{References}

1. Capelo JL, Carreira R, Diniz M, Fernandes L, Galesio M, Lodeiro $C$, et al. Overview on modern approaches to speed up protein identification workflows relying on enzymatic cleavage and mass spectrometry-based techniques. Anal Chim Acta. 2009;650:151-9.

http://dx.doi.org/10.1016/j.aca.2009.07.034

2. Pramanik BN, Mirza UA, Ing YH, Liu YH, Bartner PL, Weber PC, Bose AK. Microwave-enhanced enzyme reaction for protein mapping by mass spectrometry: a new approach to protein digestion in minutes. Protein Sci. 2002;11:2676-87. http://dx.doi.org/10.1110/ps.0213702

3. Lin SS, Wu CH, Sun MC, Sun CM, Ho YP. Microwave-assisted enzyme-catalyzed reactions in various solvent systems. J Am Soc Mass Spectrom. 2005;16:581-8. http://dx.doi.org/10.1016/j.jasms.2005.01.012

4. Reddy PM, Hsu WY, Hu JF, Ho YP. Digestion completeness of microwave-assisted and conventional trypsin-catalyzed reactions. J Am Soc Mass Spectrom. 2010;21:421-4. http://dx.doi.org/10.1016/j.jasms.2009.11.006

5. Sun W, Gao S, Wang L, Chen Y, Wu S, Wang X, et al. Microwave-assisted protein preparation and enzymatic digestion 
in proteomics. Mol Cell Proteomics. 2006;5:769-76. http://dx.doi.org/10.1074/mcp.T500022-MCP200

6. Damm M, Nusshold C, Cantillo D, Rechberger GN, Gruber $\mathrm{K}$, Sattler W, Kappe CO. Can electromagnetic fields influence the structure and enzymatic digest of proteins? A critical evaluation of microwave-assisted proteomics protocols. J Proteomics. 2012;75:5533-43. http://dx.doi.org/10.1016/j.jprot.2012.07.043

7. Ha NY, Kim SH, Lee TG, Han SY. Rapid characterization of protein chips using microwave-assisted protein tryptic digestion and MALDI mass spectrometry. Langmuir. 2011;27: 10098-105. http://dx.doi.org/10.1021/la201812a

8. Hahn HW, Rainer M, Ringer T, Huck CW, Bonn GK. Ultrafast microwave-assisted in-tip digestion of proteins. J Prot Res. 2009;8:4225-30. http://dx.doi.org/10.1021/pr900188x

9. Hofmann $\mathrm{K}$. The influence of heat on meat proteins, studied by SDS electrophoresis. In: Høyem T, Kvåle O, editors. Physical, chemical and biological changes in food caused by thermal processing. London, UK: Applied Science Publishers Ltd; 1977. pp. 311-27.

10. Tornberg E. Effects of heat on meat proteins - implications on structure and quality of meat products. Meat Sci. 2005;70: 493-508. http://dx.doi.org/10.1016/j.meatsci.2004.11.021

11. Astruc T, Gatellier P, Labas R, Lhoutellier VS, Marinova P. Microstructural changes in $\mathrm{m}$. rectus abdominis bovine muscle after heating. Meat Sci. 2010;85:743-51. http://dx.doi.org/10.1016/j.meatsci.2010.03.035

12. Montowska M, Alexander MR, Tucker GA, Barrett DA. Rapid detection of peptide markers for authentication purposes in raw and cooked meat using ambient liquid extraction sur- face analysis mass spectrometry. Anal Chem. 2014;86:10257-65. http://dx.doi.org/10.1021/ac502449w

13. Montowska M, Alexander MR, Tucker GA, Barrett DA. Authentication of processed meat products by peptidomic analysis using rapid ambient mass spectrometry. Food Chem. 2015;187:297-304.

http://dx.doi.org/10.1016/j.foodchem.2015.04.078

14. Chambers MC, Maclean B, Burke R, Amodei D, Ruderman DL, Neumann S, et al. A cross-platform toolkit for mass spectrometry and proteomics. Nat Biotechnol. 2012;30:918-20. http://dx.doi.org/10.1038/nbt.2377

15. Mascot Server. Matrix Science Inc., Boston, MA, USA. Available from: http://www.matrixscience.com/.

16. UniProtKB/SwissProt protein sequence database. Lausanne, Switzerland: SIB Swiss Institute of Bioinformatics; 2016. Available from: http://www.uniprot.org/.

17. NCBInr protein database. Bethesda, MD, USA: National Center for Biotechnology Information (NCBI); 2016. Available from: https://www.ncbi.nlm.nih.gov/.

18. Huang F, Huang M, Xu X, Zhou G. Influence of heat on protein degradation, ultrastructure and eating quality indicators of pork. J Sci Food Agric. 2011;91:443-8. http://dx.doi.org/10.1002/jsfa.4204

19. Okitani A, Ichinose N, Itoh J, Tsuji Y, Oneda Y, Hatae K, et al. Liberation of actin from actomyosin in meats heated to $65^{\circ} \mathrm{C}$. Meat Sci. 2009;81:446-50. http://dx.doi.org/10.1016/j.meatsci.2008.09.008

20. Lill JR, Ingle ES, Liu PS, Pham V, Sandoval WN. Microwave-assisted proteomics. Mass Spectrom Rev. 2007;26:657-71. http://dx.doi.org/10.1002/mas.20140

21. Park ZY, Russell DH. Thermal denaturation: a useful technique in peptide mass mapping. Anal Chem. 2000;72:2667-70. http://dx.doi.org/10.1021/ac991444k 